\title{
COMMENTS
}

\section{The Discretionary Function Exception and Mandatory Regulations}

\author{
D. Scott Barash †
}

Under the Federal Tort Claims Act ("FTCA"), the United States is liable for tortious acts and omissions "in the same manner and to the same extent as a private individual under like circumstances." The vast expansion in theories of tortious liability has generated a wealth of commentary ${ }^{3}$ and has led to frequent

$\dagger$ B.A. 1985, Yale University; J.D. Candidate 1988, The University of Chicago.

28 U.S.C. $\S \S 1346,2671-78,2680$ (1982).

228 U.S.C. § 2674 (1982).

${ }^{3}$ Richard A. Epstein, Charles O. Gregory, Harry Kalven, Jr., Cases and Materials on Torts 860 (4th ed. 1984) ("Epstein, Torts"). See generally William P. Kratzke, The Convergence of the Discretionary Function Exception to the Federal Tort Claims Act with Limitations of Liability in Common Law Negligence, 60 St.John's L.Rev. 221 (1986)(arguing that the discretionary function exception is conceptually useless, and that common law negligence principles would effectively delineate the limits of federal liability under the FTCA).

Several commentators have discussed the discretionary function exception in the regulatory context, see W. Eugene Basanta, Federal Tort Liability for Negligent Mine Safety Inspections, 85 W.Va.L.Rev. 519, 520 (1983)("[finding] considerable dispute among the courts and often, hostility to the notion that the federal government should assume any legal liability in [regulatory or inspection] situations"); Note, Sovereign Immunity and the Discretionary Function Exception of the Alaska Tort Claims Act, 2 Alaska L.Rev. 99 (1985) (discussing Alaskan discretionary function exception similar to that contained in the FTCA); Note, The Federal Seal of Approval: Government Liability for Negligent Inspection, 62 Geo.L.J. 937 (1974). Only two commentators have addressed directly the decision of the Supreme Court in United States v. Varig Airlines, 467 U.S. 797 (1984). See Comment, United States v. Varig Airlines: The Supreme Court Narrows the Scope of Government Liability under the Federal Tort Claims Act, 51 J.Air Law \& Com. 197 (1985)("Comment, Varig Airlines"); Note, United States $v$. Varig: Can the King Only Do Little Wrongs?, 22 Cal.W.L.Rev. 175, 188 (1985).

A host of pre-Varig articles focused on federal liability for negligent aircraft certification, the area specifically foreclosed by the Supreme Court in Varig. See Charles F. Krause and Joseph T. Cook, The Liability of the United States for Negligent Inspection, 48 J.Air Law \& Com. 725 (1983); Mark A. Dombroff, Certification and Inspection: An Overview of Government Liability, 47 J.Air Law \& Com. 229 (1982); John R. Harrison and Phillip J. Kolczynski, Government Liability for Certification of Aircraft?, 44 J.Air Law \& Com. 23 (1978); Cecile S. Hatfield, The Nonliability of the Government for Certification of Aircraft, 
actions against the United States for failure to discharge one of its many regulatory or supervisory functions. While such actions occasionally have succeeded, the Supreme Court in 1984 altered the scope of the FTCA by broadly construing its exception for "discretionary" conduct in United States $v$. Varig Airlines. ${ }^{4}$

The discretionary function exception to the FTCA provides that no liability shall lie for

[a]ny claim ... based upon the exercise or performance or the failure to exercise or perform a discretionary function or duty on the part of a federal agency or an employee of the Government, whether or not the discretion involved be abused. ${ }^{5}$

Because the drafters of the FTCA failed to define the term "discretionary function," the discretionary function exception has become the most litigated provision of a much litigated statute.?

Varig held that the discretionary function exception barred tort recovery for aircraft inspection procedures of the Federal Aviation Administration. Appellate courts have treated the Varig decision in contradictory ways, some interpreting Varig to mean that all regulatory activity of the government is exempt from tort liability. Other courts, taking the approach more consistent with the aims and legislative history of the FTCA, have viewed the discretionary function exception more narrowly, denying recovery only for high level "policy" decisions. ${ }^{8}$

17 Forum 602 (1982); George N. Tompkins, Jr., Liability of the United States for Negligent Certification of Aircraft, 1981 Tr.Law.Guide 370.

467 U.S. 797 (1984). See Comment, Varig Airlines, 51 J.Air Law \& Com. at 222 (eited in note 3) (The Court created a "regulatory/nonregulatory distinction that applies the discretionary function exception to the negligent operational acts of regulatory agencies").

s 28 U.S.C. $\$ 2680$ (a) (1982). While this comment discusses the discretionary function exception only in a regulatory context, the exception applies to all tort actions against the United States.

- See Payton v. United States, 679 F.2d 475, 479 (5th Cir. 1982)(“This omission [of a definition of 'discretionary function'] is understandable in light of the fact that the courts have struggled for nearly three decades to provide such a definition, with limited success").

7 Epstein, Torts at 859 (cited in note 3). The annotations following 28 U.S.C.A. $\$$ 2680(a) run over 100 pages, listing many more cases than any other FTCA provision. See Lester S. Jayson, 2 Handling Federal Tort Claims \$ 248.01 at 12-20 (1986) ("Jayson"), arguing that "[p]robably, no other provision of the Federal Tort Claims Act has been regarded as more difficult to understand or to apply."

See 2 Jayson $\$ 249.05$ at $12-128$ (cited in note 7) ("There are sharply differing views as to how far the Varig case goes in immunizing the Government from tort claims arising out of regulatory activities. Some are of the view that Varig immunizes all activity involved in the regulatory process (apart from the day-to-day activities such as driving a vehicle). Others take the position that only those acts within the process which are themselves discretionary are protected by the exclusion")(emphasis in original). 
This comment will examine state law requirements which form the basis of an FTCA cause of action, the rationale and legislative history of the Act concerning regulatory activity, Supreme Court precedent surrounding the discretionary function exception, and federal court cases interpreting the Varig decision. Drawing upon this analysis and upon an analogy to administrative law principles requiring agencies to follow their own procedures, this comment will conclude that the government should be liable under the FTCA if an official negligently fails to follow mandatory regulations.

\section{A Threshold Matter: Liability for Negligent Inspection and Regulation Under State Law and the Restatement}

A central provision of the FTCA is that the United States shall be liable for its torts "in the same manner and to the same extent as a private individual under like circumstances." This concept of "analogous private liability" requires federal courts to look to state tort law causes of action in determining FTCA liability. ${ }^{10}$

Recovery from the federal government for negligent inspection or regulation frequently is based on a "good samaritan" theory of liability as defined by sections 323 and $324 \mathrm{~A}$ of the Restatement (Second) of Torts. ${ }^{11}$ Good samaritan liability for negligent inspec-

28 U.S.C. $\$ 2674$ (1982).

${ }^{10}$ In an FTCA case, the federal district court looks to the jurisdiction where the allegedly negligent act or omission occurred to determine the applicable law. 28 U.S.C. $§ 1346$ (b) (1982); Richards v. United States, 369 U.S. 1, 9 (1962).

11 Restatement (Second) of Torts $\$ 323$ and 324A (1965) provide:

$\S$ 323. Negligent Performance of Undertaking to Render Services

One who undertakes, gratuitously or for consideration, to render services to another which he should recognize as necessary for the protection of the other's person or things, is subject to liability to the other for physical harm resulting from his failure to exercise reasonable care to perform his undertaking, if

(a) his failure to exercise such care increases the risk of such harm, or

(b) the harm is suffered because of the other's reliance upon the undertaking.

$\S 324 \mathrm{~A}$. Liability to Third Person for Negligent Performance of Undertaking One who undertakes, gratuitously or for consideration, to render services to another which he should recognize as necessary for the protection of a third person or his things, is subject to liability to the third person for physical harm resulting from his failure to exercise reasonable care to protect his undertaking, if

(a) his failure to exercise reasonable care increases the risk of such harm, or

(b) he has undertaken to perform a duty owed by the other to the third person, or

(c) the harm is suffered because of reliance of the other or the third person upon the undertaking.

See Basanta, 85 W.Va.L.Rev. at 534-59 (cited in note 3) (concluding that state good samari- 
tion and regulation has received a mixed response in the federal courts, ${ }^{12}$ but many state courts have adopted the Restatement formulation and imposed a duty on private and governmental parties to conduct inspections with reasonable care in such contexts as insurance company and municipal fire inspections. ${ }^{13}$

$\tan$ doctrines must form the basis for an FTCA cause of action). The article contains an extremely thorough discussion of the good samaritan theory of recovery under the FTCA.

${ }^{12}$ For federal decisions which have rejected the good samaritan theory, see Merklin v. United States, 788 F.2d 172, 175 (3rd Cir. 1986) (cause of action based on New Jersey good samaritan rule failed because the discretion of the Atomic Energy Commission in regulating nuclear plants "appears unbounded"); Arvanis v. Noslo Engineering Consultants, Inc., 739 F.2d 1287, 1291 (7th Cir. 1984)(The good samaritan doctrine does not apply where the government has not acted. Section 324A "refers to misfeasance - by one who needn't have acted at all"); Barnson v. United States, 630 F.Supp. 418, 421 (D. Utah 1985)("Because discretionary acts are immune regardless of whether they are negligent, the existence of a good samaritan duty is irrelevant to the discretionary function inquiry."), aff'd 816 F.2d 549 (10th Cir. 1987).

But see United Scottish Ins. v. United States, 692 F.2d 1205, 1211 (9th Cir. 1982)(private person inspecting for airworthiness liable under California "good samaritan" standard), rev'd as Varig Airlines, 467 U.S. 797 (1984); United Scottish Ins. Co. v. United States, 614 F.2d 188 (9th Cir. 1979), rev'd as Varig Airlines, 467 U.S. 797 (1984); Indian Towing Co. v. United States, 350 U.S. 61, 69 (1955). The government in Varig had asked the Supreme Court to consider whether the lower court had erred in applying California's good samaritan doctrine to the FAA certification process, but the Court declined to do so, claiming that the application of the doctrine is "at bottom a question of state law." 467 U.S. at 815 n.12.

1s See Beasley v. MacDonald Engineering Co., 287 Ala. 189, 249 So.2d 844, 847 (1971)(workers' compensation inspector assumes duty to conduct inspection with reasonable care); Adams v. State, 555 P.2d 235 (Alaska 1976), superseded by statute as stated in Wilson v. Anchorage, 669 P.2d 569 (Alaska 1983); Jefferson County School District R-1 v. Justus, 725 P.2d 767, 772 (Colo. 1986)(factual issue existed as to whether school district undertook to protect school children, and the court applied the Restatement); Manors of Inverrary XII v. Atreco-Florida, Inc., 438 So.2d 490, 492 (Fla.App. 1983)(municipality may be held liable for negligence of its building inspector in approving plans, specifications, and construction which did not meet building code requirements); Huggins v. Aetna Casualty \& Surety Co., 245 Ga. 248, 264 S.E.2d 191, 192, on remand 154 Ga.App. 559, 269 S.E.2d 471 (1980) (reliance by either employee or employer on insurance company's inspections gives rise to cause of action for negligent inspection, adopting Restatement rule); Rawson v. United Steelworkers of America, 726 P.2d 742, 750 (Idaho 1986)(using Restatement analysis, court held that because union had contracted to and had in fact inspected a mine, it owed duty to its members to exercise due care in inspecting and reporting the findings of its inspection), vacated on other grounds by United Steelworkers of America v. Rawson, 107 S.Ct. 2475 (1987); Nelson v. Union Wire Rope Corp., 31 Ill.2d. 69, 199 N.E.2d 769, 778 (1964); Perry v. Northern Indiana Public Service Co., 433 N.E.2d 44, 50 (Ind.App. 1982); Thompson v. Bohlken, 312 N.W.2d 501, 507 (Iowa 1981)(adopting Restatement § 324A); Ingram v. Howard-NeedlesTammen and Bergendoff, 234 Kan. 289, 672 P.2d 1083, 1086-87 (1983); Kennard v. Liberty Mutual Ins. Co., 277 So.2d 170, 172 (La.App. 1973); Smith v. Allendale Mutual Ins. Co., 410 Mich. 685, 303 N.W.2d 702 (1981); Brown v. Michigan Millers Mutual Ins. Co., 665 S.W.2d 630, 632 (Mo.App. 1983); Bauer v. 141-149 Cedar Lane Holding Co., 24 N.J. 139, 130 A.2d 833, 837-38 (1957); Corson v. Liberty Mutual Ins. Co., 110 N.H. 210, 265 A.2d 315, 317 (1970); City of Denton v. Van Page, 701 S.W.2d 831 (Tx. 1986); Brown v. MacPherson's, Inc., 86 Wash.2d 293, 545 P.2d 13, 18 (1975); Campbell v. City of Bellevue, 85 Wash.2d 1, 530 P.2d 234, 241 (1975); Coffey v. Milwaukee, 74 Wisc.2d 526, 247 N.W.2d 132, 137 (1976). 
In order for an inspector or regulator to be liable for negligent inspection under the Restatement formulation, the inspector must have undertaken to perform a duty, and either the inspection must increase the risk, or the party being inspected must have relied on the inspection to ensure safety.

Although its answer seems obvious, the initial question under the Restatement-whether the government has undertaken to perform a duty on behalf of the parties it inspects-has provoked some controversy. A few courts have held that because the government engages in inspection and regulatory activities for independent motives (to promote public safety, to ensure compliance with laws, etc.), such activities do not constitute an "undertaking" as contemplated by the Restatement. ${ }^{14}$ The better view of this question is that while government inspections certainly further societal goals, the inspection nonetheless provides distinct benefits to those being inspected or regulated, and that the government intends to confer those benefits in addition to pursuing its own objectives. ${ }^{15}$

Assuming the government has undertaken to perform a duty, the Restatement test then asks whether the inspection has increased the risk of harm. Courts have interpreted this standard to mean that the risk must increase in a material way beyond merely

See generally Note, State Tort Liability for Negligent Fire Inspection, 13 Colum.J.L. \& Soc.Prob. 303 (1977); Note, Campbell v. City of Bellevue: Municipal Liability for Negligent Inspections, 12 Willamette L.J. 188 (1975). For additional cases see W. Page Keeton, Dan B. Dobbs, Robert E. Keeton, David G. Owen, Prosser and Keeton on The Law of Torts, $\S 56$ at 381 n.82 (5th ed. 1984)(noting "a number of cases in which a liability insurer, making a voluntary inspection of premises to determine their safety for the purpose of workmen's compensation insurance, has been held liable to an injured workman, for its negligence in doing so"); In re Franklin National Bank Securities Litigation, 478 F.Supp. 210, 216 (E.D.N.Y. 1979)(recognizing the "emerging trend of state decisions predicating liability upon negligent fire or electrical inspections").

${ }^{14}$ In re Franklin National Bank Securities Litigation, 478 F.Supp. at 216, notes this distinction, stating that regulations regarding fire or electrical hazards "can be more easily characterized as intended for the benefit and safety of those inspected. The primary goal of bank regulation, however, can most appropriately for our purposes be viewed as the protection of the national economy and banking system-not the protection of individual institutions." See also Taylor v. United States, 521 F.Supp. 185, 188 (W.D.Ky. 1981).

${ }^{15}$ See Raymer v. United States, 660 F.2d 1136, 1143-44 (6th Cir. 1981); Barnson v. United States, 531 F.Supp. 614, 620 (D.Utah 1982), later proceeding 630 F.Supp. 418 (D.Utah 1985)(statutorily authorized regulations can constitute an undertaking despite the fact that other governmental objectives are promoted), aff'd 816 F.2d 549 (10th Cir. 1987); Basanta, 85 W.Va.L.Rev. at 545, 546-59 (cited in note 3) ("To conclude that government inspections do not constitute an undertaking to render services to others because the government may serve some of its own purposes in conducting mine inspections or because statutes such as the Mine Health and Safety Act place the primary responsibility for safety on the employer, seems to ignore reality and the stated purposes of such statutes"). 
allowing the unsafe condition to continue. ${ }^{16}$ If a federal inspector, for example, requires a safety modification which itself creates a different hazardous condition, then the inspector's actions would fall within this provision of the Restatement.

The facts of Hylin $v$. United States ${ }^{17}$ illustrate this type of liability. A Mine Enforcement Safety Administration inspector had cited a mine operator for violation of a mandatory safety standard which required that all conveyors either have handrails or be equipped with emergency stop devices. A defective junction box was located near the conveyor. The operator chose to erect a handrail along the conveyor, which narrowed the passageway between the defective junction box and the handrail to fourteen inches. The modification required by the inspector increased the risk to Hylin, who was electrocuted when walking along the narrowed path.

One would expect-and hope-that there would be only very few cases where an inspection actually increased the risk of harm. Where the inspection has not increased the risk of harm, the Restatement permits an alternative avenue of recovery. This avenue holds the regulator or inspector liable in circumstances where the injured parties relied on the defendant's undertaking. Several courts, however, have narrowly defined "reliance" to mean that plaintiffs or their employers must depend exclusively on federal inspection for safety protection and that they must forego other remedies or precautions. ${ }^{18}$ In effect, the government must "preempt" the field in order for reliance to be justified under this view. ${ }^{19}$

In the areas of FAA and mine inspection, then, this interpretation would deny recovery to plaintiffs because in each case the statutory framework rests the ultimate responsibility for safety on the employer or manufacturer, not on the government. ${ }^{20}$ Such a reading is problematic because the government may escape liability for its actions, no matter how great an involvement it has in the

${ }^{16}$ Patentas v. United States, 687 F.2d 707, 716-17 (3rd Cir. 1982); Raymer, 660 F.2d at 1143 ("[I]t is clear that the . . . [actions of] the mine inspectors in the present case did not increase the danger of harm. ... [Their actions] merely permitted the continuation of an existing risk").

17755 F.2d 551 (7th Cir. 1985).

18 Patentas, 687 F.2d at 717; Raymer, 660 F.2d at 1143-44; Blessing v. United States, 447 F.Supp. 1160, 1197-1200 (E.D.Pa. 1978).

19 Basanta, 85 W.Va.L.Rev. at 555 (cited in note 3). The "preemption" view is similar to requiring the inspector or regulator to assume the duty completely, rather than sharing the duty of care with the employer or manufacturer.

${ }^{20}$ See Raymer, 660 F.2d at 1143 (Language of Mine Health and Safety Act negates the idea that responsibility for mine safety had shifted to the government. Under the FTCA, the role of the Bureau of Mines in promoting safety was strictly secondary). 
regulation, simply by placing a boilerplate provision in the statute to the effect that final responsibility for safety lies with the party being inspected. ${ }^{21}$ Construing the reliance requirement of the Restatement so narrowly is troubling for a more important reason: it fails to take into account the possibility that a duty for safety may be shared, and that simply because a party did not rely completely on federal regulations does not mean that party did not rely at all. While it clearly would be unreasonable for a party to rely totally on federal inspections, it would not be unreasonable to rely partially on such inspections, particularly when those inspections are intended to be an overlay of safety on an already presumably safe undertaking. Federal inspection and regulation is not meant to supplant the duties of the employer or manufacturer; however, it is intended to provide an additional margin of safety. ${ }^{22}$

It makes sense to impose a stricter reliance requirement on the parties actually being regulated. In Varig Airlines, ${ }^{23}$ for example, the airline sued the government for property damage allegedly caused by the FAA's negligent inspection of the airline. In that case, imposing a strict reliance requirement on Varig seems rational because part of the duty to prevent such property damage fell upon Varig itself. To require total reliance on federal inspections by the airline in order for injured third party passengers to recover is illogical, however, because the passengers are not a part of the safety arrangements between the airline and the inspectors.

The evolution of state tort doctrines of good samaritan liability suggests that a broader construction of the reliance requirement, based on a theory of general dependence and foreseeable harm rather than the strict, total reliance which some courts presently require, is the more desirable approach and is in fact the direction in which more progressive courts are proceeding. ${ }^{24}$

The ultimate result may be to abandon the good samaritan model altogether. The historical development of American administrative law suggests that judicial resistance to government liability reflects an antiquated view of the government's role as regula-

${ }^{21}$ Of course, if Congress really wanted to prevent regulatory agencies from being sued, it could amend the FTCA itself. The potential problem of Congress inserting boilerplate provisions to absolve the government from liability therefore is probably not a great one. The agencies themselves, however, may have more of an incentive to promulgate regulations which attempt to place ultimate responsibiliy for safety and compliance on the party being regulated.

${ }^{22}$ Blessing, 447 F.Supp. at 1196.

${ }^{23} 467$ U.S. 797 (1984).

${ }^{24}$ See Basanta, 85 W.Va.L.Rev. at 552-56 (cited in note 3). 
tor. Because political demands for regulation are strong and because regulation often forms the baseline for private conduct, the premise that when the government chooses to regulate, it (like the good samaritan) should enjoy broad immunity from suit is no longer compatible with a modern administrative state. ${ }^{25}$

Rather than basing liability on the good samaritan doctrine, a more appropriate theory of recovery may be to find negligence where there has been deviation from accepted practices. For example, violation of a statute generally is considered negligence per se, ${ }^{26}$ just as "[n]onconformity to custom may be used to show negligence." 27 An increasingly frequent variant upon this principle is the admission of safety codes promulgated by industries, trade associations, or government departments for the guidance of operations within their field of interest or jurisdiction. ${ }^{28}$ Grounding liability on deviation from one's own promulgated standards is an appropriate means of allocating fault and responsibility in a modern administrative state.

\section{Legislative History of the FTCA Concerning Regulatory Activity}

The two overriding goals of the FTCA were to compensate parties injured due to governmental acts or omissions and to eliminate the inefficient and unfair system of private bills which formerly provided the sole source of governmental relief. ${ }^{29}$ The FTCA, at bottom, was designed to provide a recovery for injured

${ }^{25}$ For an excellent survey of the historical development in administrative law, see Richard B. Stewart, The Reformation of American Administrative Law, 88 Harv.L.Rev. 1667, 1805-1813 (1975).

${ }^{26}$ Fowler V. Harper, Fleming James, Oscar S. Gray, 3 The Law of Torts $\$ 17.6$ at 619 (2d ed. 1986)("Harper")("Probably, a majority of American courts have adopted the rule that the unexcused violation of . . . a statutory standard is negligence per se, that is, negligence as a matter of law. ....")

${ }^{27} 3$ Harper $\$ 17.3$ at 580 (cited in note 26). For a survey of cases, see id. at 580 n. 3.

${ }^{28}$ See, e.g., John Henry Wigmore, 2 Evidence in Trials at Common Law $\$ 461$ at 607 (Chadbourn rev. 1979); McComish v. DeSoi, 42 N.J. 274, 200 A.2d 116 (1964) (codes admitted included American Tiger Brand Wire Rope, United States Steel, United States Army Corps of Engineers, United States Navy Safety Precautions); Dixon v. International Harvester Co., 754 F.2d 573, 582 (5th Cir. 1985)(admitted Standards of American National Standards Institute while applying Mississippi law); Ruhs v. Pacific Power \& Light Co., 671 F.2d 1268 (10th Cir. 1982) (allowing evidence of deviation from National Electric Safety Code); Hurley v. Connecticut Co., 118 Conn. 276, 172 A. 86 (1934) (departure from a selfimposed and self-recognized standard of care constituted evidence of negligence).

${ }^{29}$ See Tort Claims Against the United States, Hearings on $\mathbf{S . 2 6 9 0}$ before a Subcommittee of the Senate Committee on the Judiciary, 76th Cong., 3d Sess. 6 (1940)(statement of Alexander Holtzoff, Special Assistant to Attorney General)("Hearings on S.2690"); 1 Jayson, $\S 65.01$ at 3-3 (cited in note 7). 
parties based on governmental fault. ${ }^{30}$ Before enactment of the FTCA, a party injured by a government actor was forced to petition Congress for relief via a private bill. The private bill system caused many problems for Congress, and a general sentiment arose that injured parties should have a right to recover for harms caused by the government, rather than being subjected to Congress' "grace" in passing a private bill. ${ }^{31}$

The legislative history of the FTCA evidences great concern for providing remedies for persons injured by the common law torts of government agents. The classic, rather hackneyed, illustration of this type of tort-the postal truck hitting the pedestrian-was a prominent example in hearings on bills considered prior to the final enactment of the FTCA. ${ }^{32}$

Despite the many versions of the FTCA considered in the early 1940 s, legislative history on the application of the discretionary function exception to regulatory and inspection activities is scarce. Although Congress did not when enacting the FTCA specifically address the full implications of the discretionary function exception for the regulatory sphere, it did express concern over the possibility that regulatory agencies might be held liable for their activities. The House of Representatives report on the final version of the FTCA calls the discretionary function exception a "highly important exception"

designed to preclude application of the bill to a claim against a regulatory agency, such as the Federal Trade Commission and the Securities and Exchange Commission, based upon an alleged abuse of discretionary authority by an officer or em-

${ }^{30}$ In Feres v. United States, 340 U.S. 135, $139-40$ (1950) the Court stated that the FTCA was "not an isolated and spontaneous flash of congressional generosity. It marks the culmination of a long effort to mitigate unjust consequences of sovereign immunity from suit. . . . As the Federal Government expanded its activities, its agents caused a multiplying number of remediless wrongs-wrongs which would have been actionable if inflicted by an individual or a corporation but remediless solely because their perpetrator was an officer or employee of the Government. . . The primary purpose of the Act was to extend a remedy to those who had been without").

${ }^{31}$ Hearings on S.2690 at 34 (cited in note 29). In the seventieth Congress, for example, 2,268 private bills were introduced, asking more than $\$ 100,000,000$ from the government. 336 were enacted, with total Congressional appropriations totalling $\$ 2,830,000$. See Hearings on H.R. 5373 and H.R. 6463 before the House Committee on the Judiciary, 77th Cong., 2d Sess. 11, 25, Appendix III at 56 (1942) ("Hearings on H.R. 5373 and H.R. 6463"); Tort Claims Against the United States, H.R.Rep. No. 1287, 79th Cong., 1st Sess. (1945); Edwin M. Borchard, The Federal Tort Claims Bill, 1 U.Chi.L.Rev. 1 (1933)(discussing early congressional efforts to enact tort claims legislation).

${ }^{32}$ Hearings on S.2690 at 34 (cited in note 29); Hearings on H.R. 5373 and H.R. 6463 at 9 (cited in note 31 ). 
ployee, whether or not negligence is alleged to have been involved. To take another example, claims based upon an allegedly negligent exercise by the Treasury Department of the blacklisting or freezing powers are also intended to be excepted. The bill is not intended to authorize a suit for damages to test the validity of, or provide a remedy on account of, such discretionary acts, even though negligently performed and involving an abuse of discretion. . . . However, the common-law torts of employees of regulatory agencies would be included within the scope of the bill to the same extent as torts of nonregulatory agencies. ${ }^{33}$

Early versions of the FTCA exempted the Securities and Exchange Commission and the Federal Trade Commission by name from liability in their regulatory capacities. ${ }^{34}$ Even after specific references to those agencies were dropped, the SEC and FTC remained the prime examples of regulatory bodies to which the discretionary function exception would apply. ${ }^{35}$

While the legislative history does not indicate the specific acts of these agencies that Congress had in mind, it would seem that exempting the SEC and FTC from tort liability was intended to prevent suits for economic harms allegedly inflicted on private parties as a result of SEC and FTC regulations. It is untenable to read this brief legislative report, as some courts have, to express Congress's intent that no regulatory and inspection activities of the government can give rise to tort liability. Congress simply did not indicate precisely what it meant by the "common-law torts" of government officials.

Because Congress did not confront directly the problem of tort liability for negligent federal regulation and inspection, the rationale of the FTCA must be considered to determine whether it supports holding government agencies liable for negligent inspection

${ }^{33}$ H.R.Rep. No. 1287 at 5-6 (cited in note 31). Almost identical language appears in legislative history of earlier versions of the FTCA. See Hearings on H.R. 5373 and H.R. 6463 at 28, 33 (statement of Francis M. Shea, Assistant Attorney General) (cited in note 31); Providing For The Adjustment of Certain Tort Claims Against The United States And Conferring Jurisdiction In Respect Thereto On the District Courts Of The United States, Sen.Rep. No. 1196, 77th Cong., 2d Sess. 7 (1942); Tort Claims Against the United States, H.R. Rep. No. 2245, 77th Cong., 2d Sess. 10 (1942).

34 See Tort Claims Against the United States, H.R.Rep. No. 2428, 76th Cong., 3d Sess. 5 (1940)(discussing $\$ 303$ of H.R. 7236 exempting the FTC and SEC).

${ }^{35}$ Sen.Rep. No. 1196 at 7 (cited in note 33); H.R.Rep. No. 2245 at 10 (cited in note 33); H.Rep. No. 1287 at 6 (cited in note 31 ). 
in a given situation. ${ }^{36} \mathrm{~A}$ common canon of statutory construction provides one possible argument against allowing liability for negligent inspection or regulation: because Congress created the FTCA against a backdrop of sovereign immunity, Congress intended sovereign immunity to continue as the prevailing rule except where it specifically provided otherwise. The problem with this argument is that Congress did not list any specific situations where the government should be held liable; it simply adopted state law causes of action. Had it intended to preserve vestiges of sovereign immunity, Congress would (or at least should) have chosen a more careful method of partially waiving sovereign immunity. The Court's pronouncement in Indian Towing $v$. United States ${ }^{37}$ that the FTCA "cuts the ground from under" the doctrine of sovereign immunity demonstrates its perception that the FTCA emphasizes recovery based on governmental fault. ${ }^{38}$

The concept of "analogous private liability", a dominant aspect of the FTCA recovery scheme, points against a blanket exemption for all regulatory and inspection activities of the United States. Congress explicitly and unequivocally based federal tort liability on underlying state law causes of action-as state liability developed so too would the federal government's liability. The implication is that Congress favored evolution in theories of recovery when it enacted the FTCA.

A counterargument to this point could be that Congress simply did not contemplate the current level of judicial activism in the tort field when it based FTCA liability on state causes of action. This argument is undercut by the fact that the good samaritan cause of action, which is the basis for recovery in the majority of suits brought for negligent inspection or regulation, was well known at the time Congress enacted the FTCA in $1946 .{ }^{39}$ Private parties had been liable for negligent boiler and elevator inspection in cases from the nineteenth century. ${ }^{40}$

${ }^{36}$ See Jayvee Brand, Inc. v. United States, 721 F.2d 385, 396 (D.C.Cir. 1983) (Lumbard concurring).

${ }^{37} 350$ U.S. 61,65 (1955).

${ }^{38}$ See Feres v. United States, 340 U.S. $135,139-40$ (1950).

30 William L. Prosser, Handbook of the Law of Torts 190 (1st ed. 1941) notes the rule that "if the defendant enters upon an affirmative course of conduct affecting the interests of another, he is regarded as assuming a duty to act, and will thereafter be liable for negligent acts or omissions." At common law, the premise that deviation from custom, statute or habit is evidence of negligence was also well known at the time. See notes 26-28.

${ }^{40}$ See Westinghouse Electric Elevator Co. v. Hatcher, 133 F.2d 109 (5th Cir. 1943); Cowles v. Independent Elevator Co., 22 Cal.App.2d 109, 70 P.2d 711 (1937); Bradley v. Hartford Steam-Boiler Inspection \& Ins. Co., 19 F. 246 (C.C.Pa. 1883); Annotation, Breach 
Prosser stated in 1941 that " $[t]$ he precise point at which the defendant may be said to have assumed [an affirmative good samaritan] duty is not easy to state in any general terms."41 This statement is as true today as it was in 1941, and it is an important factor in assessing congressional intent regarding the FTCA. The scope of the good samaritan duty was uncertain at the time the FTCA was passed; in adopting the prevailing common law regime, Congress presumably intended to adopt that regime's uncertainties as well.

A broad reading of the discretionary function exception conflicts with congressional intent in another, less obvious way. Congress' repeated appropriation of funds to pay FTCA judgments ${ }^{42}$ strongly indicates that Congress, rather than being dissatisfied with FTCA damage awards and narrow judicial application of the discretionary function exception, has ratified the narrow construction of that exception as an appropriate fulfillment of congressional intent in enacting the FTCA. ${ }^{43}$ In light of the unamended statute and judicial decisions which have tended to construe the discretionary function exception broadly, holding all regulatory activity exempt from liability represents a rejection of inferred congressional intent.

\section{The Crooked Path From Dalehite to Varig}

\section{A. The Broad Exception of Dalehite and the Court's Retreat}

If a plaintiff injured due to negligent regulation or inspection can satisfy the FTCA requirement of a state law cause of action, he or she still must confront the daunting wall of contradictory and confused federal court decisions construing the discretionary function exception in regulatory and other contexts.

The Supreme Court first addressed the discretionary function

of Assumed Duty to Inspect Property As Ground of Liability for Damage or Injury to Third Person, 6 A.L.R.2d 284 (1949); Restatement of Torts $\S \S 323-25$ (1934).

11 Prosser at 196 (cited in note 39).

12 Figures concerning the dollar amounts of FTCA judgments are extremely difficult to obtain. Appropriations made for payment of damages are not chargeable to budgets of individual agencies, and Congress has authorized a permanent appropriation to pay judgments from the general fund of the Treasury. Supplemental Appropriations Act, $C h$. xiv, Pub.L.No. 95-26, 91 Stat. 96 (1977). See Department of the Treasury, Appendix to the Budget of the United States Government for Fiscal Year 1987 I-S10, which states that $\$ 260,152,000$ was paid for total court judgments against the government in 1985 and an estimated $\$ 270,000,000$ in 1986 and 1987 . This figure is not broken down into its components, so one cannot tell what percentage of these judgments were paid on FTCA cases.

${ }^{43}$ Collins v. United States, 783 F.2d 1225, 1233 (5th Cir. 1986)(Brown concurring). 
exception to the FTCA in Dalehite $v$. United States, ${ }^{44}$ a case which for many years was the leading decision on the subject and which remains seminal today. ${ }^{46}$ The case arose out of an explosion of fertilizer produced and distributed by order of the United States for export to Europe after World War II. Various acts of the government were alleged as negligent: the cabinet-level decision to institute the fertilizer export program, the failure to experiment with the fertilizer to determine the possibility of explosion, the drafting of the basic plan of manufacture, and the failure to properly supervise the storage and loading of the fertilizer. ${ }^{46}$

The Court construed the discretionary function exception broadly, concluding that all of the allegedly negligent acts were discretionary and that the plaintiff's claims were therefore barred. In barring all claims against the government, the Court in Dalehite did not distinguish carefully between the policy judgment to proceed with the fertilizer shipment program and the implementation of the policy directive. ${ }^{47}$ Dalehite is persuasive in holding that the cabinet level decision to institute the fertilizer export program falls within the discretionary function exception, and the failure to conduct further experimentation as to the properties of ammonium nitrate is arguably discretionary. It seems apparent, however, that specifications for fertilizer bag labels and maximum bagging temperatures do not involve the kind of policy "discretion" that the exception was designed to protect. ${ }^{48}$

The Court extended discretionary function immunity so far down the chain of command because it felt that the allegedly negligent acts were "performed under the direction of a plan developed at a high level under a direct delegation of plan-making authority from the apex of the Executive Department." 49 The governmental conduct was at a "planning rather than operational level."

4446 U.S. 15 (1953).

${ }^{45}$ See 2 Jayson $\$ 248.01$ at 12-20 (cited in note 7)(Dalehite is "unquestionably the leading case on the subject" of the discretionary function exception).

48346 U.S. at $23-24$.

${ }^{47}$ In fact, the Court in Dalehite specifically noted that "no individual acts of negligence could be shown." Id. at 23 .

${ }^{48}$ Id. at 37-38. See also id. at 58 (Jackson dissenting) ("The common sense of this matter is that a policy adopted in the exercise of an immune discretion was carried out carelessly by those in charge of detail. We cannot agree that all the way down the line there is immunity for every balancing of care against cost, of safety against production, of warning against silence").

49 Id. at 40.

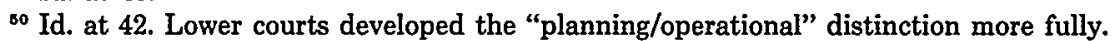
In Swanson v. United States, 229 F.Supp. 217 (N.D.Cal. 1964), the court explained the significance of the distinction: 
Court held not only that the discretionary function exception bars tort claims against the government for initiation or failure to initiate government programs, but also that it forbids claims questioning "determinations made by executives or administrators in establishing plans, specifications or schedules of operations ... [w] here there is room for policy judgment and decision." Court went even farther, however, and appeared to forget its division of government acts into planning and operational aspects, by stating that "acts of subordinates in carrying out the operations of government in accordance with official directions cannot be actionable." $" 52$ This scheme left the government liable for only the classic scenario of a postal truck hitting a pedestrian-the Court's reading of the discretionary function exception had replaced the common law rule of "the king can do no wrong" with a rule that the king could do only "little wrongs."

In Indian Towing Co., Inc. v. United States, ${ }^{54}$ the Court retreated from its broad definition of "discretion" in Dalehite. ${ }^{.5}$ The case developed the so-called "planning. versus operational" distinction, which had been articulated but ignored in Dalehite, as a basis for liability under the FTCA. In Indian Towing, a tugboat owner sued the United States to recover for property damage suffered when a lighthouse operated by the Coast Guard was inoperative, allegedly due to negligent maintenance. The Court emphasized the discretionary nature of the decision to install a lighthouse in the

The planning level notion refers to decisions involving questions of policy, that is, the evaluation of factors such as the financial, political, economic, and social effects of a given plan or policy. . . The operations level decision, on the other hand, involves decisions relating to the normal day-by-day operations of the government. Decisions made at this level may involve the exercise of discretion but not the evaluation of policy factors.

229 F.Supp. at 220 (citations omitted). Distinguishing between "planning" and "operational" decisions is often difficult. See Alabama Electric Cooperative, Inc. v. United States, 769 F.2d 1523, 1527-28 n.1 (11th Cir. 1985)(“The planning/operational distinction does not purport to be a 'test' by which the government's acts are to be measured; instead, the planning/operational distinction amounts to little more than a conclusion for a result").

s1 346 U.S. at $35-36$.

${ }^{82}$ Id. at 36.

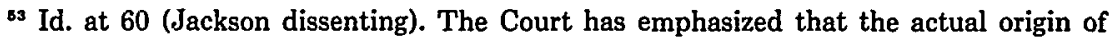
sovereign immunity was not that the king could do no wrong, but that the sovereign is immune from any suit to which it has not consented. Feres v. United States, 340 U.S. at $139-40$.

${ }^{84} 350$ U.S. 61 (1955). The Indian Towing opinion, a 5-4 decision, was written by Justice Frankfurter, who had dissented in Dalehite. Justice Reed, author of the majority opinion in Dalehite, dissented in Indian Towing.

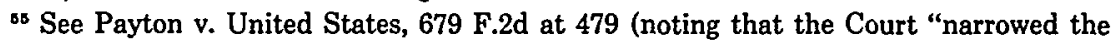
Dalehite guidelines in later opinions"). 
first place, but maintained that once the Coast Guard decided to provide the lighthouse service, it was required to do so nonnegligently. ${ }^{56}$

The government had argued in Indian Towing that since private persons do not install and maintain lighthouses, the government cannot be liable, because the FTCA speaks of liability only for that which a private person would be liable "under like circumstances." would deny liability for "uniquely governmental functions," pointing out that "we would be attributing bizarre motives to Congress were we to hold that it was predicating liability on such a completely fortuitous circumstance-the presence or absence of identical private activity." 58 The Court did not require a showing of nonunique governmental activity because it feared plunging into the " 'non-governmental'-'governmental' quagmire that has long plagued the law of municipal corporations."

In Rayonier, Inc. $v$. United States, ${ }^{60}$ the Court held that the United States was not immune from liability for negligence by the Forest Service in fighting a forest fire on private land. ${ }^{61}$ The Court, while not explicitly construing the discretionary function exception, followed Indian Towing. The Court rejected the United States's argument that it was not liable because fighting forest fires was a "uniquely governmental" activity. ${ }^{62}$ The Court noted that

[i]t may be that it is "novel and unprecedented" to hold the United States accountable for the negligence of its firefighters, but the very purpose of the Tort Claims Act was to waive the Government's traditional all-encompassing immunity from tort actions and to establish novel and unprecedented govern-

s8 350 U.S. at 69.

3728 U.S.C. $\S 2674$.

58350 U.S. at 67.

${ }^{89}$ Id. at 65. Another case, Eastern Airlines, Inc. v. Union Trust Co., 221 F.2d 62 (D.C.Cir. 1955), aff'd per curiam as United States v. Union Trust Co., 350 U.S. 907 (1955), involved a suit by survivors of victims of a midair collision against the United States under the FTCA, alleging that the negligence of air traffic controllers in clearing two planes to land on the same runway at the same time caused the collision. The Supreme Court summarily affirmed the Court of Appeals for the District of Columbia Circuit, holding Indian Towing to be controlling. The lower court, exploring the contours of the planning-operational distinction, pointed out that "discretion was exercised when it was decided to operate the tower, but the tower personnel had no discretion to operate it negligently," and held that "tower operators merely handle operational details which are outside the area of the discretionary functions and duties referred to in $\$ 2680$ (a)." $221 \mathrm{~F} .2 \mathrm{~d}$ at 73, 76-77.

${ }^{60} 352$ U.S. 315 (1957).

${ }^{61}$ Id. at $317-18$.

62 Id. at 319. 
mental liability. ${ }^{63}$

Because Washington law recognized a cause of action for negligent firefighting, the Court held that plaintiffs' claims stated a cause of action under the FTCA. ${ }^{64}$

The Court's decisions construing the FTCA generally and the discretionary function exception in particular indicate a struggle to find clear terminology and an appropriate conceptual framework with which to decide various claims of FTCA liability. The Court had never addressed fully the application of the discretionary function exception to the regulatory and inspection sphere, however, and the extent to which the exception applied in these contexts was unclear prior to Varig.

\section{B. VARIG Attempts to Clear the Muddle}

On July 11, 1973, while enroute to Paris from Rio de Janeiro, a fire broke out in one of the lavatories of a Varig Airlines Boeing 707 aircraft, killing 124 of the 135 persons on board. Varig sought damages for the destroyed aircraft and families of the passengers pressed claims for wrongful death under the Federal Tort Claims Act. The plaintiffs asserted that a waste receptacle in the 707 was incapable of containing fire, in violation of an air safety regulation requiring that such containers be made of fire resistant materials and incorporate covers to contain potential blazes. The District Court for the Central District of California granted summary judgment for the United States on the ground that California law did not recognize an actionable tort duty for inspection and certification activities and, alternatively, that even if plaintiffs had stated a cause of action under California law, recovery was barred by both the discretionary function and misrepresentation exceptions ${ }^{65}$ to

${ }^{63}$ Id.

64 The Court noted that the "plain natural meaning" of 28 U.S.C. $\S \S 2674$ and 1346(b) "make[s] the United States liable to petitioners for the Forest Service's negligence in fighting the forest fire if, as alleged in the complaints, Washington law would impose liability on private persons or corporations under similar circumstances." 352 U.S. at 318.

${ }^{\text {es }} 28$ U.S.C. $\S 2680$ (h). The misrepresentation exception is part of a more general exception to the FTCA, $\S 2680(\mathrm{~h})$, which provides that the government shall not be liable for "[a]ny claim arising out of assault, battery, false imprisonment, false arrest, malicious prosecution, abuse of process, libel, slander, misrepresentation, deceit, or interference with contract rights."

The question whether the misrepresentation exception operates to bar a claim based on government regulation and inspection was addressed in Block v. Neal, 460 U.S. 289 (1983). Neal claimed that a Farmers Home Administration ("FmHA") inspector negligently inspected a prefabricated house that the FmHA financed for plaintiff. Being careful to address only the misrepresentation question, see 460 U.S. at 294 , the Court held that the misrepre- 
the FTCA. The Ninth Circuit reversed, holding both that the California good samaritan rule would recognize a tort cause of action for negligent inspection and that such a cause of action would not be barred by either the misrepresentation or discretionary function exceptions. ${ }^{66}$

A companion case to Varig, United States $v$. United Scottish Insurance Co. ${ }^{67}$ involved the 1968 crash of a DeHavilland Dove aircraft used in an air taxi operation in Nevada. The accident, caused by an inflight fire in the forward baggage compartment, killed all four persons aboard. Several years before the crash, a previous owner had contracted with a firm to install a gasoline burning cabin heater in the plane, a modification requiring Federal Aviation Administration (FAA) certification. After submitting its drawings, plans, and other data sufficient to establish that the altered aircraft continued to meet airworthiness requirements set by the FAA, and after an FAA inspector examined the plane, the firm applied for and received a "supplemental type certificate" from the FAA.

After the crash, the owner filed an action for property damage against the United States under the FTCA and the insurers sought reimbursement for payments made on the owner's liability insurance. The district court found that the crash resulted from defective installation of the gasoline line leading to the heater, and concluded that the installation did not comply with the applicable FAA regulations. The court held that the government was negligent in certifying an installation that did not comply with the FAA's requirements. The Ninth Circuit remanded to determine whether the California courts would apply the good samaritan doctrine to government regulators, and the district court found in the affirmative. On the second appeal, the Ninth Circuit upheld the district court, deciding United Scottish and Varig on the same day.

In Varig, the Supreme Court held that the alleged negligent

sentation exception applies only to "pecuniary injuries which are wholly attributable to reliance on the Government's negligent misstatements," not those injuries which may result from faulty government regulation or inspection. 460 U.S. at 297. The FmHA inspector's misstatements were not the heart of Neal's claim; the gravamen was the injury done to her property allegedly as a result of the inspector's negligence. See Note, Torts-Misrepresentation Exception in FTCA Actions Involving Government Inspection and Certification, 49 J.Air Law \& Com. 647 (1984).

${ }^{B E}$ The Court's discussion of the facts and procedural history of Varig can be found at 467 U.S. at 799-802.

${ }^{87} 467$ U.S. 797 (1984). 
inspection and certification programs of the FAA could not give rise to tort liability under the FTCA. After reviewing the facts of Varig and United Scottish, ${ }^{68}$ the Court discussed extensively the FAA certification process, the legislative history of the FTCA, and its prior holdings in Dalehite, Indian Towing, and Eastern Airlines. ${ }^{69}$

In holding that FAA inspections cannot give rise to federal liability under the FTCA, the Court emphasized the discretionary nature of the certification process itself. The process involved numerous "spot-checks," with responsibility regarding what and when to inspect allocated to the individual inspector. In addition, the FAA was granted statutory authority to delegate certain inspection and certification responsibilities to qualified private persons, generally employees of aircraft manufacturers. FAA inspectors, then, were specifically empowered to make their own judgments and to take calculated risks as to what should be inspected. ${ }^{70}$ The ultimate duty to insure the safety of the aircraft, the Court noted, was on the manufacturer-the FAA exists merely to police compliance with the regulations. ${ }^{71}$ The decision was unanimous against federal liability. The Court discussed the discretionary function exception as if all regulatory activity might be protected from liability, with quite sweeping dicta. The two primary concerns of the Varig Court merit closer examination:

First, it is the nature of the conduct, rather than the status of the actor, that governs whether the discretionary function exception applies in a given case. . . Thus, the basic inquiry concerning the application of the discretionary function exception is whether the challenged acts of a Government employee-whatever his or her rank-are of the nature and quality that Congress intended to shield from tort liability.

Second, whatever else the discretionary function exception may include, it plainly was intended to encompass the

\footnotetext{
${ }^{68}$ For the Court's discussion of the facts and procedural history of United Scottish see Varig, 467 U.S. at 802-04.

89 467 U.S. at 804-14. See section III.A of this comment.

${ }^{70}$ Id. at 804-07. The Court noted that "[w]ith fewer than 400 engineers, the FAA obviously cannot complete this elaborate compliance review process [of new aircraft types] alone." Id. at 807.

"Id. at 821 . The "FAA has a statutory duty to promote safety in air transportation, not to insure it" (emphasis in original). Such statements, however, are little more than assertions of an erroneous conclusion, because the language of the FTCA specifically requires courts to look to the law of the jurisdiction in which the accident occurs to determine whether that jurisdiction would impose liability for negligent inspection.
} 
discretionary acts of the Government acting in its role as a regulator of the conduct of private individuals. . . . Congress wished to prevent judicial "second-guessing" of legislative and administrative decisions grounded in social, economic, and political policy through the medium of an action in tort. ${ }^{72}$

With regard to regulatory activities, the Court's apparent assertion that the discretionary function exception bars FTCA claims for improper regulation is severely undercut by the Court's use of the phrase "discretionary acts of the Government acting in its role as a regulator." While some courts have interpreted this language to mean that all regulatory activity is exempt from tort liability, ${ }^{73}$ the Court specifically stated that only "discretionary acts" which are part of the regulatory process are exempt from liability. The language is not as broad as it first appears-by including the words "discretionary acts of the government," the Court actually places the analysis back at square one. Formulating a workable definition of "discretionary act" by focusing upon the nature of the conduct, not the status of the actor, remains the primary task.

The Court's conclusion is also ambiguous in that its discussion focused exclusively upon the discretionary structure of the FAA, while ignoring the possibility of a nondiscretionary negligent inspection. Several commentators have pointed out that the Court apparently failed to grasp an essential distinction between the facts of Varig and United Scottish. ${ }^{74}$ The plaintiffs in Varig were challenging the failure of the FAA to inspect the particular 707 involved in the crash. The plaintiffs in United Scottish, however, were pressing a claim for a negligently conducted inspection-their argument was that an FAA inspector actually examined the heater in question and failed to note the hazardous gasoline line. The Court, erroneously it seems, believed that neither the Boeing 707 trash can nor the DeHavilland Dove cabin heater were actually inspected, ${ }^{78}$ while the district court in United Scottish had explicitly found that the FAA had inspected the cabin heater. ${ }^{76}$ The factual differences between Varig and United Scottish are crucial to understanding the potential breadth of, and confusion lurking be-

32467 U.S. at 813-14.

${ }^{73}$ See cases discussed in section IV.A of this comment.

${ }^{74}$ See Comment, Varig Airlines, 51 J.Air Law \& Com. at 218-20 (cited in note 3); Note, 22 Cal.W.L.Rev. at 188 (cited in note 3).

${ }^{35} 467$ U.S. at 814.

${ }^{78}$ See 614 F.2d at 190. 
hind, the Court's decision. ${ }^{77}$

The Court's failure to note this distinction casts doubt on the application of Varig to cases of negligent inspection. Deciding which aircraft to inspect is certainly a discretionary act; no court or commentator takes issue with that proposition. Once a particular aircraft, or mine, or drug, is actually inspected pursuant to authorized procedures, however, the government should not be absolved of liability if it does so negligently.

Uncertainty also exists regarding whether the planning versus operational distinction developed in Dalehite and later cases survived the Varig decision. Some courts and commentators argue that Varig, by focusing on the discretionary nature of the challenged conduct and acts rather than the level of the actor, essentially eliminated the planning versus operational distinction. ${ }^{\mathbf{7}}$ Others, however, have argued that the planning versus operational test survives, and is in fact the proper method for determining whether governmental conduct will be subject to tort liability. ${ }^{79}$ The planning versus operational test is basically a sound, common sense inquiry, and it is doubtful that the Court intended to jettison it entirely without making such an intention explicit.

While Chief Justice Burger was certainly correct when he stated in Varig that "the Court's reading of the Act admittedly has

77 See Jayson, § 249.05 at 12-128, 12-129 (cited in note 7), posing a hypothetical:

[S] uppose the FAA regulations and manuals had specifically mandated inspection of particular items and had set forth clear standards for such inspection. In that situation, it could hardly be contended that the inspector himself had any discretionary authority of his own in making his inspection. Assume further that in making his inspection, the inspector negligently failed to discover obvious defects, and a certification was issued based on his negligent report. . . . The Varig opinion provides no clean-cut answer to whether, as in the supposed case, the inspector's non-discretionary negligent conduct is clothed with immunity simply because his activity is part of an overall regulatory process.

78 See Jayson, $\S 249.01$ at $12-39$ (cited in note 7); Johnston v. United States, 597 F.Supp. 374, 434 (D.Kan. 1984) (dicta stating that Varig rejected the "planning level/operational level line of cases adopted by various courts").

79 See Alabama Electric Cooperative, Inc. v. United States, 769 F.2d 1523, 1527 (11th Cir. 1985)("Varig Airlines supports the planning/operational distinction developed by the lower courts in cases subsequent to Dalehite"); Drake Towing Co., Inc. v. Meisner Marine Constr. Co., 765 F.2d 1060, 1064 (11th Cir. 1985)(applied "planning-operational" test, holding that initial decision to place temporary navigational aids was within Coast Guard's discretion, but that the failure to properly maintain the navigational aids did not fall within discretionary function exception); Lopez-Pacheco v. United States, 627 F.Supp. 1224, 1230 (D.P.R. 1986)("The Supreme Court recently confirmed that the proper standard to be applied is the 'planning-operational' test."), aff'd 815 F.2d 692 (1st Cir. 1987); Note, Sovereign Immunity and the Discretionary Function Exception of the Alaska Tort Claims Act, 2 Alaska L.Rev. 99, 100 (1985)(arguing for a return to a "pure application" of the planningoperational distinction). 
not followed a straight line,"80 the Varig decision itself did little to eliminate the cloud of confusion surrounding the discretionary function exception. Not only was the planning/operational issue unresolved by the Court, but the Court left unclear the issues of whether and to what extent the government should be liable for its regulatory and inspection activities.

\section{AfTer VARIG: FTCA Liability for Regulatory Activity IN The Federal Courts}

One of the most striking gaps in the Varig opinion is its failure to indicate whether the United States government may be liable under the FTCA for negligent inspection or regulation in contexts other than aircraft inspection. ${ }^{81}$ Several federal courts have considered the issue, some holding that Varig extends the discretionary function exception to insulate the entire sphere of regulatory activities of the federal government from FTCA liability, while others, focusing on the specific regulations involved, have allowed causes of action for negligent inspection.

\section{A. A Blanket Exemption For Regulatory Activity?}

Courts which have created a blanket prohibition on federal liability for regulatory activities have been either unwilling or unable to distinguish other regulatory schemes from the FAA certifi-

so 467 U.S. at 811.

s2 Post-Varig lower court decisions have with few exceptions held that any regulatory action of the FAA is within the discretionary function exception. See, e.g., Waymire v. United States, 629 F.Supp. 1396, 1403 (D.Kan. 1986)(FAA inspector, even following mandatory guidelines for airworthiness inspection, acting within scope of discretionary function exception); Proctor v. United States, 622 F.Supp. 10, 12 (C.D.Cal. 1984), aff'd 781 F.2d 752 (9th Cir. 1986)(noting that "the entire FAA certification process is immune from potential tort liability"); Heller v. United States, 620 F.Supp. 270 (M.D.Fla. 1985)(FAA medical certification process held discretionary), aff'd 803 F.2d 1558 (11th Cir. 1986); Sottile v. United States, 608 F.Supp. 1040, 1043 (D.D.C. 1984)(decision of FAA to investigate flight instructor and decision to continue investigation within discretionary function exception); Wendler v. United States, 606 F.Supp. 148 (D.Kan. 1985), aff'd 782 F.2d 853 (10th Cir. 1985)(any negligence by FAA in suspension or processing of plaintiff's commercial pilot certificate within discretionary function exception).

But see Colorado Flying Academy, Inc. v. United States, 724 F.2d 871, 875 (10th Cir. 1984)(administrative decisions involved in designing terminal control area surrounding the Denver airport were within discretionary function exception, but if "mandatory guidelines existed and they were violated, then the discretionary function exception would not bar recovery"); Beattie v. United States, 592 F.Supp. 780, 784 n.25 (D.D.C. 1984) (court noted that Varig "appears to indicate that the discretionary function exception does not apply to the negligence of air traffic controllers and related acts of supervisors"), aff'd 756 F.2d 91 (D.C. Cir. 1984). 
cation process in Varig. In Hylin v. United States, ${ }^{82}$ for example, the Seventh Circuit barred a claim by the wife of a man electrocuted when he came in contact with a defective electrical junction box in a passageway of a mine which had been inspected by the Mine Enforcement and Safety Administration (MESA). Hylin sued the government under two theories of Illinois tort law: (1) the negligent failure of the MESA to inspect and cite for correction the defective junction box; and (2) the enforcement of the mandatory safety standard on conveyors had either created or enhanced the risk of injury from the defective junction box. ${ }^{83}$ The Seventh Circuit, reconsidering an earlier opinion recognizing the plaintiff's cause of action, ${ }^{84}$ held that the enforcement activities of MESA are protected by the discretionary function exception to the FTCA. ${ }^{85}$

The Seventh Circuit rejected the plaintiff's argument that the regulations at issue in Hylin were mandatory and hence the inspector could have no "discretion" to violate them. The court explained, "[w] hether the government was in fact negligent is irrelevant to the analysis" of the application of the discretionary function exception since "Varig Airlines teaches that we must examine the nature of the challenged governmental activity."88

The Hylin court, recognizing the great weight the Supreme Court placed on the specific FAA regulations involved in Varig, noted that the regulatory scheme of MESA was distinguishable from that of the FAA, because "MESA is required by statute to conduct periodic inspections of mines" subject to the Federal Metal and Nonmetallic Mine Safety Act of $1966{ }^{87}$ The court apparently viewed this distinction as irrelevant to the question whether the inspector was covered by the discretionary function exception. ${ }^{88}$

${ }^{82} 755$ F.2d 551 (7th Cir. 1985).

${ }^{83}$ Id.

34 The prior decision was reported at 715 F.2d 1206 (7th Cir. 1983), vacated in light of Varig at 469 U.S. 807 (1984).

os 755 F.2d at 554 .

${ }^{86}$ Id. at 553 .

${ }^{87}$ Id. at 554 (emphasis added); 30 U.S.C. $\$ 721$ et seq. (1970), repealed in 1977 and replaced by the Federal Mine Safety and Health Act of 1977, 30 U.S.C. $\S 801$ et seq. (1982). The 1977 Act became effective only after the accident that gave rise to Hylin. $755 \mathrm{~F} .2 \mathrm{~d}$ at 554 n.3.

88 The Tenth Circuit, in Russell v. United States, 763 F.2d 786 (10th Cir. 1985), took a position similar to that of the Seventh, holding that coal mine inspections under the Federal Mine Safety and Health Amendments Act of 1977, 30 U.S.C. $\S \S 801-962$, fell within the discretionary function exception of the FTCA. The court in Russell stated that "[l]ike the Seventh Circuit, we see no principled distinction between the cause of action asserted here and that rejected in Varig Airlines." 763 F.2d at 787. 
While the discretion at issue in Varig was the discretion of whether to inspect certain aircraft at all, the discretion in Hylin was limited to discretion in the execution of the inspection itself. The Hylin court, however, read Varig as standing for the proposition that

[i]f the regulatory inspection and enforcement activities of an agency require its employees to exercise discretion in performing their duties, the discretionary function exception bars tort claims against the government based upon those performances. ${ }^{89}$

Although this definition of "discretion" is certainly plausible, it is broad enough to swallow the potential tort liability of the government entirely. Practically any act can be characterized as "discretionary" in some sense. ${ }^{30}$ Particularly in the mine inspection situation, the fact that a federal agency was required to inspect each mine points not to a broad exception for all regulatory activity, but to a close factual analysis of the particular regulations in question to determine the extent of the individual inspector's or regulator's discretion.

Other courts which have rejected FTCA liability for regulatory or inspection activity have emphasized that the government is not to be an insurer of private parties and a damages suit is not the appropriate challenge to improper regulations or inspections.

The Fourth Circuit, for example, in holding that the decision of the FAA to postpone regulating ultralight aircraft was a proper exercise of governmental discretion, noted that post-Varig cases

stand for the general proposition that the federal government, at least when it is performing a discretionary function, will not be held liable for torts caused by the negligent conduct of third parties, even though the government agency had a statutory mandate to regulate the conduct of the private parties.

s8 755 F.2d at 553 .

${ }^{\circ 0}$ See Hugh C. Stromswold, The Twilight Zone of the Federal Tort Claims Act, 4 Am.U.I.L.Rev. 41, 46 (1955), noting the "conspicuous inanity" of such a definition of discretion, and pointing out that "pushed to the only well-defined boundary, it would exempt the entire federal structure since all federal activity is to some extent traceable to basic policy decisions. As aptly expressed by the Supreme Court itself in a somewhat different context [U.S. v. Yellow Cab, 340 U.S. 543 (1950)]: 'No sensible reason can be imagined why a State having consented to be sued would then paralyze the remedy.' " See also Ham v. Los Angeles County, 46 Cal.App. 148, 189 P. 462, 468 (1920) ("It would be difficult to conceive of any official act, no matter how directly ministerial, that did not admit of some discretion in the manner of its performance, even if it involved the driving of a nail"). 
We simply do not agree with the plaintiff's argument that an FTCA suit is an essential check on an agency that purportedly refuses to comply with a statute. The purpose of the FTCA is to provide individuals with a means of obtaining tort damages from the United States for injuries negligently inflicted by U.S. employees or agents, and it should not be used to solve the entirely separate, modern problem of alleged bureaucratic inaction and ineptitude. ${ }^{91}$

Other courts have agreed, concluding that the entire sphere of governmental regulatory activity is exempt from tort liability. ${ }^{\boldsymbol{9}}$ Such courts are certainly correct when they assert that an FTCA action is not the appropriate means to correct bureaucratic problems - this is simply the separation of powers argument of Dalehite and Varig, that courts should not second-guess executive decisions, cast in different terms. ${ }^{93}$ What these courts do not recognize, however, is that beyond the separation of powers concerns lie issues of duty of care and adequate compensation for injured parties, two issues that Congress intended to address when it enacted the FTCA. ${ }^{94}$

\section{B. Negligent Execution of Mandatory Regulations is Not Exempt} From FTCA Liability.

Recognizing gaps in the Varig analysis, some courts have argued that " $[t]$ he discretionary function exception does not immunize failure to comply with a mandatory duty,"95 even in a regulatory context. These courts emphasize the fact that almost any act

92 Baxley v. United States, 767 F.2d 1095, 1098 (4th Cir. 1985).

${ }^{22}$ See Allen v. United States, 816 F.2d 1417, 1424 (10th Cir. 1987) (following Hylin, the court found "all challenged actions surrounding the government atomic bomb tests in the 1950 s and 1960s to be immune from suit"); Bacon v. United States, 810 F.2d 827 (8th Cir. 1987) (EPA's decision not to warn property owners about dioxin contamination fell within the discretionary function exception); Cunningham v. United States, 625 F.Supp. 1016, 1020 (D.Mont. 1985), aff'd 786 F.2d 1445 (9th Cir. 1986)("Under the Varig rule, the monitoring function performed by OSHA inspectors is exempt from Tort Claims Act liability"); Totten v. United States, 618 F.Supp. 951, 954 (E.D.Tenn. 1985) (the "mere fact that controlling military safety regulations were not followed does not, of itself, give rise to a cause of action in tort and while this may be evidence of negligence per se, the discretionary function exception of Section 2680(a) protects the United States from liability even when negligence can be proved"), aff'd 806 F.2d 698 (6th Cir. 1986); Ayala v. Joy Manufacturing Co., 610 F.Supp. 86, 87, 90 (D.Colo. 1985)(decisions of Mine Health and Safety Act inspector are discretionary; even failure to comply with a "mandatory-nonoptional" instruction falls within the exception).

${ }^{23}$ See section III of this comment.

" Section $\mathrm{V}$ of this comment discusses these policy issues more extensively.

${ }^{23}$ Barnson v. United States, 630 F.Supp. at 422. 
can be characterized as discretionary, and that a factual inquiry into the actual nature of the conduct being questioned is required to determine whether the government should be liable under the FTCA. This approach is consistent with the Supreme Court's reasoning and the policies underlying the FTCA.

Courts which allow causes of action against the United States based on negligent inspection emphasize that to read Varig as creating a blanket exclusion for regulatory activities would be an unwarranted expansion of the discretionary function exception. For example, in Collins v. United States ${ }^{96}$ the Fifth Circuit, rejecting the broad interpretation of Varig and the discretionary function exception, refused to grant the government's motion to dismiss a claim resulting from an allegedly negligent mine inspection. The government argued that regulatory activity is discretionary conduct as a matter of law, and is therefore shielded from actions under the FTCA. ${ }^{97}$ The Fifth Circuit, in rejecting this contention, noted that "[n]either the language nor the structure of the decision in Varig supports such a view."98 The Collins court termed the government's position as "radically extending Varig to mean that whenever challenged conduct is regulatory in nature, the conduct is per se discretionary and, as such, shielded from exposure to private tort actions."

The facts of Collins presented a strong case for imposing liability upon the government for negligent inspection. After conducting a three day inspection, a Mine Safety and Health Administration inspector issued an "Imminent Danger Order" classifying the mine as hazardous and requiring that the mine in question be closed until suitable safety equipment was installed. The plaintiffs in Collins contended that the inspector's supervisor terminated the Imminent Danger Order, suppressed or tampered with air samples, and instructed subordinates to relax their inspection of the mine. The plaintiffs asserted that the MSHA's failure to reclassify the mine and require correction of the dangerous condition caused their injuries. ${ }^{100}$ The plaintiffs' claims in Collins focused not on the initiation of programs or determinations made in establishing plans, specifications, or schedules of operations, nor on the agency's choice of its regulatory scheme, but rather "entirely on

${ }^{98} 783$ F.2d 1225 (5th Cir. 1986).

${ }^{87} \mathrm{Id}$. at 1228.

${ }^{88}$ Id. at 1229.

89 Id. at 1228.

${ }^{100} \mathrm{Id}$. at 1227. 
the acts of subordinates in 'carrying out [or failing to carry out] the operations of government in accordance with official directions'-in this instance statutory and regulatory provisions."101

The court emphasized that the "United States is not liable for damages based on challenges necessarily directed at an agency's discretion, if it exists, in determining the extent to which it will regulate or the manner in which this will be done," but maintained that if an agency has not delegated discretion to an inspector, the government will be liable for that inspector's negligent acts under the FTCA. ${ }^{102}$ The discretionary function exception "protects only discretionary conduct; not all regulatory conduct is discretionary conduct. Discretionary conduct requires room for policy analysis and judgment."103

The fact that the inspector in Collins was bound by mandatory inspection guidelines weighed heavily in the court's decision. Similarly, the Eighth Circuit held in McMichael $v$. United States $^{\mathbf{1 0 4}}$ that the discretionary function exception did not bar plaintiffs' cause of action for deaths and injuries caused by an explosion at a government contractor's munitions plant allegedly as a result of the Defense Department's failure to enforce the contractor's compliance with safety regulations. The court distinguished Varig partially on the grounds that in that case the government was acting solely in its regulatory capacity while in McMichael the government, in operating a munitions plant, was "pursuing a proprietary rather than a regulatory objective."105

The main basis for allowing the cause of action in McMichael, however, was the fact that precise inspection guidelines (the inspectors were provided with a fifty-one step procedures review checklist) promulgated by the Defense Department were not followed. "Thus," the court maintained,

the Defense Department inspectors were not called upon to make discretionary regulatory judgments. Rather, they had a number of precise inspections to perform which involved no judgment concerning agency policy. For purposes of summary judgment, the parties have stipulated that the inspectors

${ }^{101}$ Id. at 1230 , quoting Dalehite, 346 U.S. at 35-36.

${ }^{102} 783$ F.2d at 1230 . Collins explicitly disagreed with the Hylin argument that "the presence of discretion in any aspect of the regulatory process means that at any stage of it negligent conduct is within $\S 2680$ (a)." Id. at 1229 n.3.

${ }^{103}$ Id. at 1229.

104751 F.2d 303 (8th Cir. 1985).

105 Id. at 306. 
failed to enforce numerous safety requirements. In light of these distinctions from Varig, we reaffirm our prior holding ${ }^{106}$ that the government's conduct in failing to enforce the detected violations of the safety requirements is not protected as a discretionary function. ${ }^{107}$

McMichael's emphasis on the existence of precise regulatory guidelines as obviating the inspectors' discretion is an appropriate reading of Varig.

From Collins and McMichael, the crucial consideration is whether the plaintiff attacks the nature of rules which an agency has promulgated or the way in which the rules were applied (or not applied) in a specific case. ${ }^{108}$ Other courts have similarly refused to apply the discretionary function exception to the execution of mandatory guidelines or regulations. ${ }^{109}$ Specific allegations of negligence on the part of an individual regulator, one court has noted, "are a far cry from the broad challenge asserted in Varig to the regulatory scheme developed by the FAA."110

${ }^{108}$ See Madison v. United States, 679 F.2d 736 (8th Cir. 1982).

107751 F.2d at 307 (footnote added).

${ }^{108}$ See also Hendry v. United States, 418 F.2d 774, 782-83 (2d Cir. 1969), indicating that another factor is whether state law standards of negligence can adequately evaluate the course of action contemplated by a federal statute or regulation. State tort standards are certainly applicable to a negligent inspection case, see section I, but lose force when applied to those situations in which the decision-maker looked to public policy considerations and not simply to professional standards. But "[t]he fact that judgments of government officials occur in areas requiring professional expert evaluation does not necessarily remove those judgments from the examination of courts by classifying them as discretionary functions under the Act." Id. at 783.

${ }^{109}$ See, for example, Baker v. United States, 817 F.2d 560, 566 (9th Cir. 1987) ("negligent failure to obey a mandatory regulatory command" could give rise to an FTCA cause of action; complaint alleging negligence in certifying polio vaccine upheld); Feyers v. United States, 749 F.2d 1222, 1227 n. 7 (6th Cir. 1984)(dicta stating that the discretionary function exception "does not apply where mandatory guidelines or regulations are violated"); Barnson, 630 F.Supp. at 422 (dicta stating that "[i]f an agency has a mandatory duty to regulate a particular field, an exception to the usual rule applies. The discretionary function exception does not immunize failure to comply with a mandatory duty"); Waymire, 629 F.Supp. at 1399 (dicta); Andrulonis v. United States, 593 F.Supp. 1336 (N.D.N.Y. 1984)(development of oral immunization of wildlife against rabies, if negligent, not subject to discretionary function exception).

${ }^{110}$ Andrulonis, 593 F.Supp. at 1338. Similarly, in a case decided prior to, but quoted from approvingly after Varig, the Tenth Circuit noted that "if a government official in performing his statutory duties must act without reliance upon a fixed or readily ascertainable standard, the decision he makes is discretionary and within the exception to the Tort Claims Act. Conversely, if there is a standard by which his action is measured, it is not within the exception." Barton v. United States, 609 F.2d 977, 979 (10th Cir. 1979), quoted with approval in Alabama Electric Cooperative, Inc., 769 F.2d at 1529 (alleged negligent design of river dikes by Army Corps of Engineers; held, the Corps' design decisions are subject to judicial review under state tort law standards that would normally govern an 


\section{The Justifications for the Discretionary Function Excep- tion Are INAPPLiCABLe to THE NegLigent Execution of Mandatory Regulations}

Courts and commentators have identified three major policy justifications for the discretionary function exception. First, and probably foremost, the discretionary function exception promotes the separation of powers by limiting judicial scrutiny of executive decisions. ${ }^{111}$ The exception was designed "to protect the Government from liability that would seriously handicap efficient government operations."112 According to the Varig Court, Congress enacted the discretionary function exception to prevent the courts from "second-guessing" administrative or legislative decisions "grounded in social, economic, and political policy through the medium of an action in tort." "The Court noted, however, that "it is unnecessary-and indeed impossible-to define with precision every contour of the discretionary function exception." "14

In deciding to impose tort liability for negligent execution of mandatory regulatory guidelines, this separation of powers concern is simply nonexistent-the "discretion" inherent in promulgating rules and procedures in the first place is unquestionably protected from tort liability, but the "nuts and bolts" implementation of these admittedly discretionary acts should remain subject to liability, if, based on the underlying tort theory, a private party could be held liable. Moreover, the judiciary has always sought to hold the executive to its own declared policies; rule of law concerns have long supported judicial review of executive action.

A second justification, that in areas of policy making courts are ill-equipped to investigate and weigh the factors which enter

action for engineering malpractice).

But see Flammia v. United States, 739 F.2d 202, 204 (5th Cir. 1984)(“[w]e view the language of Varig Airlines to dictate that the exemption under the Federal Tort Claims Act derived from this discretion extends to specific. individual applications as well as to broad policies"; held, decision to release Cuban refugees fell within the discretionary function exception).

II Varig, 467 U.S. at 814 . See Owen v. City of Independence, 445 U.S. 622, 648 (1980)(in context of municipal functions, protecting cities from suits challenging discretionary decisions "was grounded not on the principle of sovereign immunity, but on a concern for separation of powers. . . . For a court or jury, in the guise of a tort suit, to review the reasonableness of the city's judgment on these matters would be an infringement upon the powers properly vested in a coordinate and coequal branch of government.").

112 United States v. Muniz, 374 U.S. 150, 163 (1963).

113 Varig, 467 U.S. at 814.

114 Id. at 813. See also Dalehite, 346 U.S. at 35-36. 
into decisions by other branches, ${ }^{115}$ is a variant of the separation of powers concern. Courts have long refrained from adjudicating political questions. ${ }^{118}$ Merely because a regulatory act may be political is no reason to exclude the entire regulatory sphere from tort liability-a court is certainly capable of determining when an action implicates separation of powers concerns and when it does not. "Determining whether a decision involves policy at all is not the same as scrutinizing the correctness of that. policy decision."118

The third justification, that the discretionary function exception is needed to prevent huge, unpredictable financial costs from judicial reexamination of government decisions, ${ }^{119}$ is untenable in light of the FTCA's emphasis on adequate compensation of tort victims, ${ }^{120}$ the fault-based concept of liability imposed by the statute, ${ }^{121}$ and past Congressional appropriations. ${ }^{122}$

An argument sometimes invoked against imposing liability on the government for negligently failing to follow mandatory regulatory guidelines is that to do so would discourage government agencies from establishing such guidelines and deter government from undertaking regulation and inspection at all. ${ }^{123}$ While this argument may have force when applied to a private entity engaging in inspection, such as an insurance company, several considerations dampen its force in the realm of government regulation.

First, finding a tort duty does not necessarily mean that liability will result. An injured party still must show that the government agent knew or should have known of the risks that caused

${ }^{115}$ See Hendry v. United States, 418 F.2d at 783; Payton v. United States, 679 F.2d 475, 486-87 (5th Cir. 1982) (Tjoflat concurring in part and dissenting in part).

${ }^{116}$ See Goldwater v. Carter, 444 U.S. 996 (1979); Powell v. McCormack, 395 U.S. 486 (1969); Baker v. Carr, 369 U.S. 186 (1962). The current narrow construction of the political question doctrine probably limits its application to FTCA cases. See Geoffrey R. Stone, Louis M. Seidman, Cass R. Sunstein, Mark V. Tushnet, Constitutional Law 101 (1986).

${ }^{117}$ See Alakson v. United States, 790 F.2d 688, 694 (8th Cir. 1986) ("holding [a government agency] responsible for compliance with its own safety policy regarding its electrical transmission lines will not undermine its governmental function.").

118 Collins v. United States, 783 F.2d at 1231.

110 See Payton, 679 F.2d at 486-87 (Tjoflat concurring in part and dissenting in part).

${ }^{120}$ See Indian Towing, 350 U.S. at 68-69 ("The broad and just purpose which the statute [FTCA] was designed to effect was to compensate the victims of negligence in the conduct of governmental activities in circumstances like unto those in which a private person would be liable and not to leave just treatment to the caprice and legislative burden of individual private laws."). See also section II discussing the legislative history of the FTCA. ${ }^{121}$ See Feres, 340 U.S. at $139-40$.

${ }^{122}$ Congress has provided a standing appropriation to pay FTCA judgments, apparently showing little concern about potentially disastrous damage awards against the government. See note 42.

${ }^{123}$ Blessing, 447 F.Supp. at 1199. 
the injuries and failed to act properly. ${ }^{124}$ Traditional tort doctrines of contributory negligence and proximate cause will often limit government liability in such cases. ${ }^{128}$ Additionally, imposing a duty to act reasonably may provide an incentive for the government to be more careful in conducting inspections-not to impose such a duty arguably encourages the government to use less care in its regulatory activities mandated by Congress. ${ }^{128}$

Most important, the government presumably is not as concerned with the "bottom line" as private industry - the reason why it decides to regulate in the first place is to ensure a greater measure of safety for employees, passengers, and other third parties. The narrow argument that imposing tort liability will cause the government to abandon such activity or promulgate only general guidelines ignores the many social and political factors other than FTCA liability which impinge on the government's regulatory activities. Because a significant political constituency will favor regulatory action, any incentives agencies may have to avoid FTCA exposure, will simply result in a greater political "push" by Congress, most likely in its authorization statutes, to bind agencies to a mandatory regulatory framework.

Holding all regulatory activity of the government to be exempt from FTCA liability also flouts the language of Varig itself. Varig stressed that the "nature of the conduct, rather than the status of the actor," governs application of the discretionary function. While the Court intended its statement to mean that not only actions of low level officials could give rise to FTCA liability, the implications of this test in the regulatory context are clear: the "status" of an individual government actor as regulator or inspector should be irrelevant to the analysis of whether his or her acts are discretionary-the proper focus is on what that individual actually does. In-

124 Basanta, 85 W.Va.L.Rev. at 557-58 (cited in note 3).

${ }^{125}$ In Holland v. United States, 464 F.Supp. 117 (W.D.Ky. 1978), the court found that even if a duty to conduct mine inspections reasonably could be shown, there was no negligence by the government and the government inspection was not the legal cause of plaintiff's injuries.

${ }^{128}$ Basanta, 85 W.Va.L.Rev, at 558 (cited in note 3). For example, the Occupational Safety and Health Act of 1970, 29 U.S.C. $\S \S 651-678$ (1982) was enacted for the purpose of reducing nationwide the number and severity of work-related illnesses and injuries. Imposing FTCA liability for negligent conduct of OSHA inspections furthers the congressional goal of a safe workplace-presumably, potential tort liability will encourage full compliance with inspection guidelines.

In addition, the costs to the government in carrying out its regulatory mandate by issuing regulatory guidelines are arguably less than the costs incurred when a disastrous accident occurs. Basanta, 85 W.Va.L.Rev. at 558. 
terpreting the FTCA as providing a blanket exception from liability for regulatory acts of the United States defies the reasoning, if not the dicta, of Varig.

\section{Regulatory Agencies, Like Other Administrative Bodies, Should Be Required To Follow Their MANDATORY GuideLINES}

Once a government agency decides to promulgate mandatory inspection rules or regulatory guidelines, the failure of a government agent to comply with such rules should give rise to FTCA liability. An appropriate analogy is to administrative law, where an agency is required to follow its own procedures once it promulgates them. In both the tort and the administrative agency contexts the governmental body retains discretion to issue rules and guidelines as it sees fit, but once those guidelines have been set forth, neither the government inspector nor the bureaucrat should be allowed to use his or her "discretion" to violate them.

The origin of the notion that "an agency must follow its own rules" is the Supreme Court's decision in Arizona Grocery Co. $v$. Atchison, Topeka \& Santa Fe Railway Co. ${ }^{127}$ In a challenge to the Interstate Commerce Commission's ratemaking process, the Court held that ICC rules were binding on the agency in subsequent adjudications, at least until the agency amended its policy through rulemaking procedures. ${ }^{128}$

In later decisions involving government benefits as distinguished from economic regulation, the Court emphasized that procedural due process requirements compelled agencies to follow their own rules. For example, in Morton v. Ruiz, the Court pointed out that " $[w]$ here the rights of individuals are affected, it is incumbent upon agencies to follow their own procedures. This is so even where the internal procedures are possibly more rigorous than otherwise would be required." ${ }^{129}$ Morton held that the Bureau of Indian Affairs must award benefits to a person who lived near a reservation, even though Bureau policy was to provide benefits only

127284 U.S. 370 (1932).

${ }^{128}$ See Stephen G. Breyer and Richard B. Stewart, Administrative Law and Regulatory Policy 457 (1979)("an administrative agency ruling until changed binds both the outside world and the agency").

129415 U.S. 199, 235 (1974). See Kenneth C. Davis, 2 Administrative Law Treatise § 7:21 at 100-01 (2d ed. 1979)(In Morton v. Ruiz, "the simple proposition shines through that the statement in the Manual about publishing directives in the Federal Register was binding on the BIA even though it was not a legislative rule. And the result did not depend on some unique factor about the BIA; the Court generalized about 'agencies' "). 
to individuals actually living on a reservation. The Bureau's own internal procedure manual provided that directives which inform the public as to what benefits were available should be published in the Federal Register, but the Bureau failed to publish its benefits rules. The Court was primarily concerned with the Bureau's failure to publish its directive in the Federal Register, noting that "[b]efore the BIA may extinguish the entitlement of these otherwise eligible beneficiaries, it must comply, at a minimum, with its own internal procedures." 130 The requirement that agencies follow their own procedures may apply even when such procedures afford greater protections of individual rights than the Constitution or statutes require. ${ }^{131}$

The concerns implicated by a violation of a mandatory regulation by an agency in the tort context are ostensibly different from those implicated in the administrative law context of government benefits. In administrative proceedings, the primary concerns are ensuring that the individual's right to due process is protected and promoting reasonable reliance on administrative rules by requiring the agency in question to adhere to its own standards. ${ }^{132}$ The reliance concern, however, is equally applicable in the context of regulations giving rise to potential liability under the Federal Tort Claims Act. If a government agency undertakes to regulate the conduct of certain individuals or corporations, then other groups, both those regulated and outsiders (such as passengers or employees), should be able to depend upon the governmental action: the regulatory body should be liable for neglecting to follow its own mandatory rules. ${ }^{133}$

Reliance, however, is not the only interest to be protected. As Justice Marshall pointed out in dissent in United States v. Caceres, "[t]o make subjective reliance controlling in due process analysis deflects inquiry from the relevant constitutional issue, the legitimacy of government conduct."134 Allowing regulatory bodies to

330415 U.S. at 235.

${ }^{131}$ See United States v. Caceres, 440 U.S. 741, 759-60 (1979) (Marshall dissenting).

${ }^{232}$ See Note, Violations by Agencies of Their Own Regulations, 87 Harv.L.Rev. 629, $631-42$ (1974). Agencies may occasionally have an interest in departing from regulations, id. at $642-43$, but such an interest could rarely, if ever, be shown in the context of a mandatory regulation regarding safety inspections.

${ }^{133}$ See Arizona Grocery, 284 U.S. at 389; Red Lake Band of Chippewa Indians v. United States, 800 F.2d 1187, 1196 (D.C.Cir. 1986)("A government official has no discretion to violate the binding laws, regulations, or policies that define the extent of his [or her] official powers. An employee of the government acting beyond his [or her] authority is not exercising the sort of discretion the discretionary function exception was enacted to protect.").

134440 U.S. 741, 762 (1979). 
flout their own officially promulgated guidelines with impunity undermines the integrity of regulatory conduct in general, ${ }^{135}$ and defeats Congressional intent in creating the regulatory agencies.

Requiring regulatory bodies to adhere to their own guidelines cannot and should not be used as a "back door" attack on the validity of the regulations themselves, however. The discretion of the government in promulgating, or failing to promulgate, regulations is unquestioned. ${ }^{136}$ In Jayvee Brand, Inc. v. United States, ${ }^{137}$ manufacturers of children's sleepwear brought an action alleging that the Consumer Product Safety Commission (CPSC) failed to follow procedures set forth in the Federal Food, Drug, and Cosmetic Act. The CPSC did not provide notice of the proposed ban on the flame retardant Tris in the Federal Register, and failed to receive the views of interested parties prior to the ban. The plaintiffs were attacking not the rule itself or its execution, but the procedures by which the Tris ban was formulated and adopted. The Court of Appeals for the District of Columbia Circuit rejected plaintiffs' challenge:

making a discretionary decision without following mandated procedures [i.e., failing to provide notice of the proposed ban on Tris] should be characterized, for the purposes of the FTCA, as an abuse of discretion. It follows that the discretionary function exception applies and the district court was without jurisdiction to entertain this suit. ${ }^{138}$

The court in Jayvee Brand was particularly concerned with the potential of many lawsuits challenging the propriety of administrative actions through procedural means, ${ }^{139}$ noting that "[a]ppellants ask us to make a major innovation in the law by holding that the FTCA provides damage actions as an additional means of policing the internal procedures of governmental agencies," an innovation which the court refused to undertake. ${ }^{140}$ The court did point out,

${ }^{135}$ See Note, 87 Harv.L.Rev. at 630 (cited in note 132).

${ }^{136}$ See Varig, 467 U.S. at 819-20 ("When an agency determines the extent to which it will supervise the safety procedures of private individuals, it is exercising discretionary regulatory authority of the most basic kind."); Smith v. Johns-Manville Corp., 795 F.2d 301, 309 n.13 (3d Cir. 1986); McMichael v. United States, 751 F.2d 303, 307 (8th Cir. 1985); Feyers v. United States, 749 F.2d at 1227 (6th Cir. 1984). See also Jayson, § 249.05[1] at 12-129 (cited in note 7).

${ }^{237} 721$ F.2d 385 (D.C.Cir. 1983).

138 Id. at 390.

${ }^{138}$ Id. at 391.

${ }^{140}$ Id. The court was wary of the potential broad scope of the cause of action in Jayvee Brand, id. at 393-94, noting that "at bottom we arrive at our decision because we do not 
however, that the failure of a government employee to follow obligatory procedures, even in the regulatory context, is not subject to the discretionary function exception. ${ }^{141}$

Justice Frankfurter argued in Vitarelli $v$. Seaton that "[a]n executive agency must be rigorously held to the standards by which it professes its action to be judged."142 While Justice Frankfurter spoke of administrative procedures, his words apply with equal force to mandatory regulatory activities of the government which may be subject to liability under the FTCA. If federal inspectors and regulators assume the duty of competently overseeing private activity, then those government employees should be held to tort standards of professional responsibility and due care.

\section{ConcLusion}

The rationale and legislative history of the FTCA, Supreme Court precedent, and an analogy to administrative law all support holding the federal government liable in certain situations for negligent regulation or inspection of private parties. This is not to say, however, that the government should be liable whenever a party who has been subjected to regulation is injured. FTCA liability for negligent regulation must be limited to instances in which mandatory, detailed guidelines cabining the discretion of the governmental actor are violated, and in which allowing a court to determine liability would not implicate any broad policy concerns of the regulatory body.

Justice Jackson, although writing in 1953 and addressing a different set of circumstances, was startlingly prescient when he argued that "[w]e who would hold the Government liable here cannot avoid consideration of the basic criteria by which courts determine liability in the conditions of modern life. . . .Such a dependent society must exact greater care than in more simple days and must require from manufacturers or producers increased integrity and caution as the only protection of its safety and wellbeing."143 The problems of Jackson's "dependent society" are ap-

know how to confine this new cause of action were we to accept the broad principle propounded by the appellants. Any procedural irregularity in any administrative determination would give rise to a cause of action for damages."

141 Id. at 389.

112359 U.S. 535, 546 (1959) (Frankfurter dissenting).

${ }^{143}$ Dalehite, 346 U.S. at 51 (Jackson dissenting). See Stromswold, 4 Am.U.I.L.Rev. at 49 (cited in note 90) ("With perhaps some disregard for tort law niceties, these courts [which predicate federal tort liability on failure to warn] assert that when the government elects to extend itself into fields that impinge on every facet of modern life, it must assume a com- 
parent when the federal government is called upon to regulate, inspect, and certify ever more things with which we deal every day-surely the government, by assuming part of the duty to ensure a safe society, should assume part of the risk of liability when something goes wrong. 